\title{
TOLERANCE TO THE HERBICIDE CLOMAZONE AND POTENTIAL FOR CHANGES OF FOREST SPECIES
}

\author{
USO DE ESPÉCIES FLORESTAIS PARA DIMINUIÇÃO DO RESÍDUO DE \\ CLOMAZONE NO AMBIENTE
}

\section{Cássia Michelle CABRAL ${ }^{1}$; José Barbosa dos SANTOS $^{1}$; Evander Alves FERREIRA ${ }^{1}$; Vinicius Morais MACHADO ${ }^{2}$ Israel Marinho PEREIRA ${ }^{1}$; Daniel Valadão SILVA ${ }^{3}$; Matheus Freitas SOUZA ${ }^{3}$}

1. Universidade Federal dos Vales do Jequitinhonha e Mucuri, Diamantina MG. Brasil. mtchells@ yahoo.com.br; 2. Universidade de Brasília; Brasília - DF; Brasil; 3. Universidade Federal Rural do Semi-Árido, Mossoró, RN, Brasil.

\begin{abstract}
Clomazone has excelled among Brazilian non-target-site herbicides with high environmental impact. Its high solubility in water can result in leaching, contaminating groundwater and watercourses with possible riparian forest degradation. This situation can be mitigated by phytoremediation process. This study aimed to identify tree species tolerant to clomazone aiming to use them in bioremediation programs. Twelve forest species were evaluated: Inga marginata Willd, Handroanthus serratifolius (A.H. Gentry) S. Grose, Jacaranda puberula Chan, Cedrela fissilis Vell, Calophyllum brasiliense Cambess, Psidium myrsinoides Berg, Tibouchina granulosa Cogn, Caesalpinia ferrea Mart ex. Tul, Caesalpinia pluviosa DC, Terminalia argentea Mart \& Zucc, Schinopsis brasiliensis Eng and Schizolobium parahyba (Vell). The statistical analysis was performed in a completely randomized block design with four replications. Three clomazone applications were made each 20 days (60, 80 and 100 days after planting); each application was equivalent to one-half of the recommended rate $\left(2.0 \mathrm{~L} \mathrm{ha}^{-1}\right)$. The evaluated parameters were plant height, stem diameter, leaf number, leaf area and dry biomass. The forest species survived the clomazone application; and I. marginata, C. ferrea and S. brasiliensis showed increased tolerance to this herbicide, demonstrating potential for phytoremediation of areas contaminated by clomazone.
\end{abstract}

KEYWORDS: Bioremediation. Herbicide. Leaching.

\section{INTRODUCTION}

The use of in situ vegetation for purposed of contaminated soil treatment is named phytoremediation. This technique provides notable advantages, and early, may enable areas for plantation of species non-tolerant to some compounds (KOPTSIK, 2014). Phytoextraction and phytostimulation have highlighted among the remediation techniques; however, root degradation seems to be a major route for these pesticide residues in Brazilian soil (SANTOS et al., 2007).

Herbicides stand out as important pesticides for agriculture management due to high use in recent years, being an effective and economically viable weed control alternative (Inoue, et al., 2011). Nonetheless, problems related to herbicide behavior in soil have been evidenced and leaving toxic waste within soil (COBBUCI; MACHADO, 1999), which can be leached into groundwater or contaminate watercourses by runoff, making it necessary to mitigate this pollution.

The clomazone is the active ingredient of Gamit ${ }^{\circledR}$ that is an important herbicide in Brazil, and is recommended for irrigated rice, soybeans, corn, tobacco, cotton, sugarcane and cassava (MAPA,
2014) applied for pre-emergence control of several weed species. Despite its moderate persistence in soil, the product is highly soluble in water $(1,100$ $\mathrm{mg} \mathrm{L}{ }^{-1}$ at $25^{\circ} \mathrm{C}$ ) making it dangerous in abundant water environment (ESTEVEZ et al., 2008). Thus, clomazone molecule properties indicate high potential for displacement in the environment near to water streams during irrigation and drainage, which may cause intoxication to sensitive plants downstream pesticide application areas.

Clomazone belongs to isoxazolidinon chemical group, and acts by inhibiting carotenoid biosynthesis (FOROUZESH et al., 2013), being absorbed by plant through apical meristem (preferably in roots) (SCHREIBER et al., 2013). Herbicides such as hexazinone, imazapyr and sulfentrazone, clomazone, ametryn, amicarbazone and diuron were detected in semiartesian wells and springs region of the Córrego Rico-SP microbasin. Among these, clomazone was the most frequent herbicide, being detected in more than $60 \%$ of the samples (SANTOS et al., 2015). Similar evaluations were carried out in rivers and agricultural waters of the central region of Rio Grande do Sul, finding in 90\% of samples collected residues of clomazone (NALINI et al., 2016). 
Phytoremediation with tree species is an alternative for rehabilitation of degraded areas by herbicide contamination; since in general, these plants produce high biomass and extensive root systems (ASTIER et al., 2016). Studies on phytoremediation of herbicide-contaminated areas using fast-growing annual species are already available in national literature (SANTOS et al., 2007; KOPTSIK, 2014). Contrarily, tree species investigations are scarce and it has been increasingly greater the search for information on these plants to subsidize restoration projects, especially with species of riparian areas, thereby constituting as a barrier to the herbicides.

Riparian zones are essential for natural hydrological processes and are located along the banks of watercourses, reservoirs and river sources (JYVÄSJÄRVI et ål., 2014). These areas present high water saturation, at least for most of the year, due to the proximity of the groundwater or water courses. Some of the species that compose a riparian forest are able to reach deep layers in the soil profile due to the greater growth of their roots, reaching groundwater (ROOD et al., 2015). Thus, riparian species with remmediated capacity can assist in the decontamination of soil and water located at greater depths.

The current study aimed to evaluate the tolerance of twelve forest species to clomazone, so as they might be used in phytoremediation programs to recover areas contaminated by this herbicide.

\section{MATERIAL AND METHODS}

The experiment was carried out in a greenhouse of the Graduate Program in Forest Science in the Universidade Federal dos Vales do Jequitinhonha e Mucuri - UFVJM (Federal University of Jequitinhonha and Mucuri Valleys UFVJM). The statistical design was a completely randomized block with four replications. Twelve forest species of trees were evaluated: Inga marginata Willd (Fabaceae), Handroanthus serratifolius (A.H. Gentry) S.Grose (Bignoniaceae), Jacaranda puberula Chan (Bignoniaceae), Cedrela fissilis Vell (Meliaceae), Calophyllum brasiliense Cambess (Calophyllaceae), Psidium myrsinoides Berg (Myrtaceae), Tibouchina granulosa (Desr.) Cogn (Melastomataceae), Caesalpinia ferrea Mart. ex Tul (Fabaceae), Caesalpinia pluviosa DC
(Fabaceae), Terminalia argentea Mart \& Zucc (Combretaceae), Schinopsis brasiliensis Eng (Anacardiaceae) and Schizolobium parahyba (Vell.) Blake, (Fabaceae). Seedlings were acquired from the Forest Garden of the State Forest Institute (IEF) in Diamantina-MG, Brazil. Subsequently, they were grown in 5-L pots $\left(0.0314 \mathrm{~m}^{2}\right)$ filled with properly fertilized substrate. Three herbicide applications with clomazone at a 20-day interval were performed (60, 80 and 100 days after planting); each application was equivalent to one-half of the recommended rate $\left(2.0 \mathrm{~L} \mathrm{ha}^{-1}\right)$. Applications were carried out with the aid of micropipette with a manual adjustment directly on water-holding dishes under the pots, simulating water absorption by roots from a contaminated groundwater. For irrigation throughout experiment, water was placed in the dishes and absorbed by the plants through capillary, and substrate moisture kept close to $80 \%$ field capacity.

One-hundred days after the first application, plant parameters were evaluated. The assessed variables were plant height $(\mathrm{PH})$, measured from plant base up to the last leaf insertion; stem diameter (SD), measured with a caliper at two-centimeter height; leaf number (LN) and area (LA). The leaf area was determined by scanning leaf limbs in a flatbed scanner attached to a computer. Leaf area was analyzed trough an image processing software with advanced measuring - IMAGE PRO-PLUS version 4.1 for Windows $\AA$. Moreover, all collected plant material was split into roots, stems and leaves and, subsequently, dried in oven with forced air circulation at $65{ }^{\circ} \mathrm{C}$ until constant weight to determine dry mass, which was weighed in a precision balance.

Data were transformed into percentage related to control treatment, since they come from different species with different growth characteristics. Afterwards, variance analysis was performed and means, when significant, were grouped by Scott-Knott test at 5\% probability.

\section{RESULTS AND DISCUSSION}

Growth analysis of the twelve species showed significant differences for stem diameter (SD), plant height (PH), leaf number (LN) and leaf area (LA) on average of $70.8 \%$ for tested species (Table 1). 
Table 1. Plant height (PH \%), stem diameter (SD \%), leaf number (LN \%), and total leaf area (LA \%) of plants submitted to clomazone applications compared to control (100\%).

\begin{tabular}{llllllllll}
\hline Species & PH \% & & SD \% & & LA \% & & LN \% & \\
\hline Inga marginata & 113.26 & $\mathrm{a}$ & 94.07 & $\mathrm{~b}$ & 72.94 & $\mathrm{a}$ & 106.50 & $\mathrm{~b}$ \\
Handroanthus serratifolius & 92.04 & $\mathrm{~b}$ & 89.09 & $\mathrm{~b}$ & 48.54 & $\mathrm{~b}$ & 71.43 & $\mathrm{~b}$ \\
Jacaranda puberula & 110.05 & $\mathrm{a}$ & 115.43 & $\mathrm{a}$ & 83.23 & $\mathrm{a}$ & 245.83 & $\mathrm{a}$ \\
Cedrela fissilis & 89.01 & $\mathrm{~b}$ & 110.06 & $\mathrm{a}$ & 89.18 & $\mathrm{a}$ & 66.00 & $\mathrm{~b}$ \\
Calophyllum brasiliensis & 112.90 & $\mathrm{a}$ & 95.89 & $\mathrm{~b}$ & 70.59 & $\mathrm{a}$ & 75.00 & $\mathrm{~b}$ \\
Psidium mirsinoides & 88.78 & $\mathrm{~b}$ & 79.34 & $\mathrm{~b}$ & 40.65 & $\mathrm{~b}$ & 65.34 & $\mathrm{~b}$ \\
Tibouchina glandulosa & 91.53 & $\mathrm{~b}$ & 92.84 & $\mathrm{~b}$ & 89.01 & $\mathrm{a}$ & 112.16 & $\mathrm{~b}$ \\
Caesalpinia ferrea & 86.23 & $\mathrm{~b}$ & 97.93 & $\mathrm{~b}$ & 60.48 & $\mathrm{~b}$ & 251.40 & $\mathrm{a}$ \\
Caesalpinia pluviosa & 83.21 & $\mathrm{~b}$ & 113.99 & $\mathrm{a}$ & 40.59 & $\mathrm{~b}$ & 84.78 & $\mathrm{~b}$ \\
Terminalia argentea & 73.46 & $\mathrm{~b}$ & 88.65 & $\mathrm{~b}$ & 30.94 & $\mathrm{~b}$ & 24.39 & $\mathrm{c}$ \\
Schinopsis brasiliensis & 83.64 & $\mathrm{~b}$ & 105.56 & $\mathrm{a}$ & 79.56 & $\mathrm{a}$ & 127.30 & $\mathrm{~b}$ \\
Schizolobium parahyba & 93.77 & $\mathrm{~b}$ & 120.48 & $\mathrm{a}$ & 79.49 & $\mathrm{a}$ & 58.33 & $\mathrm{~b}$ \\
\hline VC\% & 20.00 & & 17.31 & & 37.64 & & 82.67 & \\
\hline
\end{tabular}

* Means followed by the same lower case letter in the column do not differ from each other by Scott knott test at 5\% probability.

Plant height was moderately reduced for most species by herbicide application, and $T$. argentea was the most negatively affected with a drop of $26.7 \%$ in height. In contrary, I. marginata, $J$. puberula and $C$. brasiliense showed a significant increase of $12 \%$ on average $(\mathrm{p}<0.05)$ for this variable (Table 1). Nevertheless, this feature by itself does not reflect a better development since height increase without stem diameter raise, which can frequently affect plant shoot support and lateral branch development weakening stem strength (STEINGRAEBER, 1982).

$H$. serratifolius, $C$. brasiliense, $P$. myrsinoides, C.ferrea, and T.argentea had negative results with respect to stem diameter, which reduced in $8.9 \%$. By contrast, C. fissilis, C. pluviosa, S. brasiliensis and $S$. parahyba had stem diameter increased, but it was not followed by height increase. S. parahyba showed an increase in stem diameter and height growth statistically close to control. It was observed a slight trend in diameter reduction for I. marginata, with no statistical significance together with height growth. As in $J$. puberula, an increase for both variables was observed (Table 1). Larger SDs suggest great availability of photo-assimilated compounds within shoot (SCALON et al., 2001). This availability indicate seedling survival potential, growth and greater adaptability, due to their high capacity of new root formation and growth (SCALON et al., 2002).

Leaf number (LN) among species was different when the clomazone was applied on plants. $T$. argentea was the most adversely affected compared to other species, with a less $\mathrm{LN}$ value, followed by $S$. parahyba, $P$. myrsinoides, $C$. brasiliense, $C$. fissilis and $H$. serratifolius (Table 1). In contrast to those results, the average increasing of $148.6 \%$ for $J$. puberula and C. ferrea (Table 1)might come from a drastic response to stress caused by herbicide. The same was observed for $I$. marginata, $T$. granulosa and $S$. brasiliensis, but to a lesser extent, with an average increase of $15.3 \%$ (Table 1). Leaf number increase might occur due to changes in plant metabolism stimulus.

Recent studies show that the number of leaves produced by plants is determined by resource allocation as compensation (LONNIE, 2012), i.e., species that produce lower mass leaves produce them in greater number per plant, in a corresponding scale. Plants with smaller leaves have greater "foliar intensity" (MILLA; REICH, 2011). The same can occur among different plants within the same species (SCOTT ; AARSSEN, 2012). The more the leaf are produced, the greater the "gem stock" is, which means more axillary meristems per plant (WHITMAN; AARSSEN, 2010). This mechanism will be available for a strategic deployment, for example, expression of plasticity architecture/growth (including branching intensity), or as a "supply" for survival and compensation after tissue loss by herbivory or disorders (LONNIE, 2012). In any above-mentioned situation, it is proved the effect of clomazone residue on vegetation downstream fields with herbicide application.

Leaf area stands out among the growth parameters once it plays on light interception and 
absorption, and plant photosynthetic capacity (SEVERINO et al., 2004), and plant-environment gas exchanges (PEREIRA et al., 1997). All assessed species were negatively affected by clomazone. $H$. serratifolius, $P$. myrsinoides, $C$. pluviosa and $T$. argentea presented the highest LA reduction rates, followed by $\mathrm{LN}$ decrease, limiting light absorption area and, consequently, affecting the photosynthetic apparatus (Table 1). The same was true for the other species except for I. marginata, T. granulosa, $S$. brasiliensis, J. puberula and C. ferrea that despite had reduced LA showed a significant increase in LF, which seems to be a compensation strategy to keep the photosynthetic rate (Table 1). With respect to $J$. puberula and $C$. ferrea, there is a LA decrease
CABRAL, M. C. et al.

of $30 \%$ despite of increase by 1.5 times of NL. The reduced leaf area is an early cellular response to low expansion, reducing the surface exposed to the sun, leaving plants less subjected to elevated transpiration and temperature increase $(\mathrm{KLICH}$, 2000).

Concerning dry biomass, the leaf growth was significantly affected by clomazone (Table 2), with an average reduction of $38.4 \%$, for most species. Corroborating results for LA, T. argentea stood out negatively with $71.2 \%$ reduction in LDM. However, C. ferrea and S. brasiliensis showed increased LDM accumulation in accordance with $\mathrm{LN}$, but contrary to LA data.

Table 2. Leaf dry mass (LDM \%), root dry mass (RDM \%), stem dry mass (SDM \%) and total dry mass (TDM $\%)$ of forest species submitted to clomazone treatments compared with control (100\%)

\begin{tabular}{|c|c|c|c|c|c|c|c|c|}
\hline Species & LDM\% & & RDM\% & & SDM\% & & TDM\% & \\
\hline Inga marginata & 88.57 & $\mathrm{~b}$ & 141.77 & $\mathrm{a}$ & 140.49 & a & 121.88 & $\mathrm{a}$ \\
\hline Handroanthus serratifolius & 44.54 & $\mathrm{c}$ & 82.44 & $\mathrm{~b}$ & 80.77 & $\mathrm{~b}$ & 74.49 & $\mathrm{~b}$ \\
\hline Jacaranda puberula & 68.80 & $\mathrm{c}$ & 137.24 & $\mathrm{a}$ & 95.24 & $\mathrm{~b}$ & 110.81 & $\mathrm{a}$ \\
\hline Cedrela fissilis & 59.62 & $\mathrm{c}$ & 115.66 & $\mathrm{a}$ & 90.15 & $\mathrm{~b}$ & 96.66 & $\mathrm{~b}$ \\
\hline Calophyllum brasiliensis & 86.20 & $\mathrm{~b}$ & 84.20 & $\mathrm{~b}$ & 118.04 & $\mathrm{a}$ & 91.82 & $\mathrm{~b}$ \\
\hline Psidium mirsinoides & 37.49 & $\mathrm{c}$ & 68.42 & $\mathrm{~b}$ & 50.37 & $\mathrm{~b}$ & 49.76 & $\mathrm{c}$ \\
\hline Tibouchina glandulosa & 93.65 & $\mathrm{~b}$ & 88.25 & $\mathrm{~b}$ & 95.78 & $\mathrm{~b}$ & 91.29 & $\mathrm{~b}$ \\
\hline Caesalpinia ferrea & 148.86 & $\mathrm{a}$ & 128.04 & $\mathrm{a}$ & 92.85 & $\mathrm{~b}$ & 120.25 & $\mathrm{a}$ \\
\hline Caesalpinia pluviosa & 40.27 & $\mathrm{c}$ & 90.30 & $\mathrm{~b}$ & 74.61 & $\mathrm{~b}$ & 78.61 & $\mathrm{~b}$ \\
\hline Terminalia argentea & 28.71 & $\mathrm{c}$ & 71.36 & $\mathrm{~b}$ & 50.75 & $\mathrm{~b}$ & 53.18 & $\mathrm{c}$ \\
\hline Schinopsis brasiliensis & 135.18 & $\mathrm{a}$ & 125.09 & $\mathrm{a}$ & 85.95 & $\mathrm{~b}$ & 113.75 & $\mathrm{a}$ \\
\hline Schizolobium parahyba & 67.31 & $\mathrm{c}$ & 85.35 & $\mathrm{~b}$ & 156.76 & $\mathrm{a}$ & 146.62 & $\mathrm{a}$ \\
\hline $\mathrm{VC} \%$ & 51,03 & & 27.19 & & 31.87 & & 23,91 & \\
\hline
\end{tabular}

For stem dry mass, it was observed that $P$. myrsinoides and $T$. argentea were the most adversely affected with an average reduction of $49.4 \%$, followed by $H$. serratifolius, $C$. ferrea and $S$. brasiliensis, which were affected in lower degree. Contrarily, I. marginata, C. brasiliense and $S$. parahyba had increased $38.4 \%$ for this variable (Table 2).

Root dry mass was moderately affected by the herbicide, with an increase of $29.6 \%$ for $I$. marginata, J. puberula, C. fissilis, C. ferra and $S$. brasiliensis; and an average reduction of $30.1 \%$ for $P$. myrsinoides and $T$. argentea and followed the other species (Table 2). Root system quality directly reflects plant survival in the field (MAFIA et al., 2005). In adaptation terms, root system imbalance can be harmful, since seedlings with well-developed roots have higher survival rates (LIMA et al., 2008).
The above cited biomass changes determine alterations in total dry matter (TDM), for which, $I$. marginata, J. puberula, C. ferrea, S. brasiliensis and $S$. parahyba had an increment of $23.4 \%$, on average, by clomazone effect (Table 2). The same was not observed for the other species, which, in general, were negatively affected with an average reduction of $23.4 \%$ (Table 2 ).

The results have evidenced clomazone intoxication on forest species, reducing plant height, leaf area and dry biomass for both shoot and root; and they come from changes in photosynthetic process (TOMCO et al., 2013).

This may occur since this herbicide acts indirectly in photosynthesis by inhibiting deoxyxylulose phosphate synthase enzyme (DXP synthase), which is responsible for isoterpenoid synthesis, the basic carotenoid precursors 
(SCHREIBER et al., 2013)) and inhibit chlorophyll photo-oxidation.

Luminosity enhances the herbicide effects, impairing species adaptation to light, which is especially important in early stages by conditioning morphogenetic and physiological modifications in structure and function (SULTAN, 2003), constituting a key factor for species establishment within a forest.

All species survived by the presence of clomazone molecule in the experiment conditions. Nevertheless, performing an associated analysis, $T$. argentea, $P$. myrsinoides and $H$. serratifolius showed results with more significant reductions (p $<0.05$ ) for almost all parameters. These results suggest that these species are sensitive to clomazone, and care should be taken when using them in recovery programs for degraded areas. Moreover, the herbicide should not be recommended in areas where such species are protected, as in riparian forest or other forest fragments downstream crops with clomazone spraying.

I. marginata, C. ferrea and S. brasiliensis showed the best results regarding herbicide tolerance. Although I. marginata presented a slight trend in LA and LDM reductions, it has maintained the standards for the other variables, with significant increase in RDM and SDM, which are important parameters on field survival (MAFIA et al., 2005). The species must have been favored since it belongs to the Fabaceae family, which consist of plant species with nitrogen-fixing bacteria association, making them ideal for nutrient poor environments and regeneration areas (GEI AND POWERS, 2015)
CABRAL, M. C. et al.

and being often associated with riparian forests (RIBEIRO ; LIMA, 2009). C. ferrea, which is also from Fabaceae family, despite its LA reduction, it was successful in LN increase strategy, supporting the ability to maintain, at these conditions, a growth rate followed by $S$. brasiliensis, which is included in the Endangered Plant Species Official list as vulnerable (SNIF, 2012).

The above mentioned species were highlighted to preserve similar characteristics to control plants, even under stress conditions. Authors such as Pires et al. (2003c), Koptsik (2014), Santos et al. (2007) and Maladão et al. (2013) emphasized that species tolerant to herbicides in soil had also showed later good performance as phytoremediators, indicating greater potential for further clomazone phytoremediation studies.

\section{CONCLUSION}

Clomazone adversely affected to a greater or lesser degree most of the forest species tested in relation to growth. However, Inga marginata, Caesalpinia ferrea and Schinopsis brasiliensis stood for tolerating the herbicide effects, remaining in good conditions. Thus, they might present potential for phytoremediation in recovery programs of areas contaminated by this herbicide.

\section{ACKNOWLEDGEMENTS}

The authors thank to the Research Support Foundation of the State of Minas Gerais (Fapemig), $\mathrm{CNPq}$ and CAPES by financial support, and the Forest State Institute (IEF) by donated seedlings.

RESUMO: Entre os herbicidas com elevado impacto ambiental em sítios não alvo no Brasil, o clomazone tem se destacado. A alta solubilidade desse herbicida em água pode resultar em lixiviação, ocasionando contaminação de mananciais de água subterrânea e cursos d'água, com possível degradação de matas ciliares. Esta circunstância pode ser mitigada por meio de processos de fitorremediação. Este trabalho objetivou identificar espécies arbóreas tolerantes ao clomazone visando utiliza-las em programas de biorremediação. Foram avaliadas doze espécies florestais: Inga marginata Willd, Handroanthus serratifolius (A.H. Gentry) S.Grose, Jacaranda puberula Chan, Cedrela fissilis Vell, Calophyllum brasiliense Cambess, Psidium myrsinoides Berg, Tibouchina granulosa Cogn, Caesalpinia ferrea Mart ex. Tul, Caesalpinia pluviosa DC, Terminalia argentea Mart \& Zucc, Schinopsis brasiliensis Eng e Schizolobium parahyba (Vell) Blake. Foi utilizado o delineamento em blocos ao acaso com quatro repetições. Foram feitas 3 aplicações do herbicida clomazone com intervalos de 20 dias (aos 60, 80 e 100 dias após o plantio), cada aplicação foi correspondente a metade da dose comercial de $2.0 \mathrm{~L} \mathrm{ha}^{-1}$. Foram avaliados a altura da planta, o diâmetro do caule, o número de folhas, a área foliar e o acúmulo de biomassa seca. Constatou-se que todas as espécies sobreviveram à aplicação de clomazone, contudo $I$. marginata, $C$. ferrea e $S$. brasiliensis apresentaram maior tolerância ao herbicida, demonstrando potencial para o uso em programas de fitorremediação de áreas contaminadas pelo clomazone.

PALAVRAS-CHAVE: Biorremediação. Herbicida. Lixiviação. 


\section{REFERENCES}

ASSIS, R. L.; PROCÓPIO, S. O.; CARMO, M. L.; PIRES, F. R.; CARGNELUTTI FILHO A.; BRAZ G. B. P. Fitorremediação de solo contaminado com o herbicida picloram por plantas de capim pé de galinha gigante.

Revista Brasileira de Engenharia Agrícola e Ambiental Campina Grande v. 14, n. 11, p. 1131-1135, 2010. ttps://doi.org/10.1590/S1415-43662010001100001

ASTIER, C.; GLOAGUEN, V.; FAUGERON, C. Phytoremediation of cadmium-contaminated soils by young Douglas fir trees: effects of cadmium exposure on cell wall composition. International journal of phytoremediation, Philadelphia, v. 16, n. 7-8, p. 790-803, 2014.

https://doi.org/10.1080/15226514.2013.856849

ESTÉVEZ, M. A.; PERIAGO, E. L.; CARBALlO, E. M.; GÁNDARA, J. S.; MEJUTO, J. C.; RÍO, L. G.; Agriculture, Ecosystems and Environment, Amsterdam, p. 123-247, 2008.

FOROUZESH, A.; ZAND, E.; SOUFIZADEH, S. Classification of herbicides according to chemical family for weed resistance management strategies-an update. Weed Research, Oxford, v. 55, n. 4, p. 334-358, 2015. https://doi.org/10.1111/wre.12153

GEI, M. G.; POWERS, J. S. The influence of seasonality and species effects on surface fine roots and nodulation in tropical legume tree plantations. Plant and soil, Holanda, v. 388, n. 1-2, p. 187-196, 2015. https://doi.org/10.1007/s11104-014-2324-1

INOUE, M. H., SANTANA, C. T. C., OLIVEIRA JR., R. S., POSSAMAI, A. C.S ., KLICH, M. G. Leaf variations in Elaeagnus angustifólia related to environmental heterogeneity. Environmental and Experimental Botany, Elmsford, v. 44, p. 171-183, 2000. https://doi.org/10.1016/S0098-8472(00)00056-3

JYVÄSJÄRVI, J., SUURKUUKKA, H., VIRTANEN, R., AROVIITA, J., \& MUOTKA, T. Does the taxonomic completeness of headwater stream assemblages reflect the conservation status of the riparian forest?. Forest Ecology and Management, Amsterdam, v. 334, p. 293-300, 2014.

https://doi.org/10.1016/j.foreco.2014.09.019

KOPTSIK, G. N. Problems and prospects concerning the phytoremediation of heavy metal polluted soils: a review. Eurasian soil science, Silver Spring, v. 47, n. 9, p. 923-939, 2014.

https://doi.org/10.1134/S1064229314090075

KLICH, M. G. Leaf variations in Elaeagnus angustifolia related to environmental heterogeneity.

Environmental and Experimental Botany, Elmsford, v. 44, n. 3, p. 171-183. 2000.

https://doi.org/10.1016/S0098-8472(00)00056-3

LIMA, J. D.; SILVA, B. M. S.; MORAIS, W. S; DANTAS, V. A. V.; ALMEIDA, C. C. Efeitos da luminosidade no crescimento de mudas de Caesalpinia ferrea Mart. ex Tul. (Leguminosae, Caesalpinoideae). Acta Amazonica, Manaus, v. 38, n. 1, p. 5 - 10, 2008. https://doi.org/10.1590/s0044-59672008000100002

LONNIE W. AARSSEN. Reducing size to increase number: a hypothesis for compound leaves. Ideas in Ecology and Evolution, Ontario v. 5, p. 1-5, 2012.

MAFIA, R. G. et al. Critério técnico para determinação da idade ótima de mudas de eucalipto para plantio. Revista Árvore, Viçosa, v. 29, n. 6, p. 947-953, 2005. https://doi.org/10.1590/S0100-67622005000600014

MADALAO, J. C. et al. Susceptibilidade de espécies de plantas com potencial de fitorremediação do herbicida sulfentrazone. Rev. Ceres,Viçosa, v. 60, n. 1, Feb. 2013. 
MAPA - Ministério de Agricultura, Pecuária e Abastecimento. AGROFIT (Sistema de Agrotóxicos fitossanitários (Consulta Aberta)). http://agrofit.agricultura.gov.br/agrofit_cons/principal_agrofit_cons Data da consulta 27-08-2012.

MARCHIORETTO, L. R; DAL MAGRO, T. Weed control and crop selectivity of post-emergence herbicides in common beans. Ciência Rural, Santa Maria, v. 47, n. 3, 2017. https://doi.org/10.1590/0103$8478 \mathrm{cr} 20160295$

MILLA, R.; REICH, P. B. Multi-trait interactions, not phylogeny, fine-tune leaf size reduction with increasing altitude. Annals of Botany, London, v. 107 p. 455-465, 2011. https://doi.org/10.1093/aob/mcq261

NALINI, R. R. P.; JANAKI, P.; BALUSAMY, M.; CHINNUSAMY, C. Persistence and Residue of Clomazone in Soil and Soybean by HPLC-DAD. Asian Journal of Chemistry, v. 28, n. 1, p. 51, 2016.

https://doi.org/10.14233/ajchem.2016.19222

PIRES, F. R. et al . Seleção de plantas com potencial para fitorremediação de tebuthiuron. Planta Daninha,Viçosa, v. 21, n. 3, 2003c

RIBEIRO. R. D. \& LIMA. H. C. Riqueza e Distribuição Geográfica de Espécies Arbóreas da Família Leguminosae e Implicações para Conservação no Centro de Diversidade Vegetal de Cabo Frio, Rio De Janeiro, Brasil. Rodriguésia, Rio de Janeiro, v. 60, n. 4, p. 111-127, 2009.

ROOD, S. B., BIGELOW, S. G., POLZIN, M. L., GILL, K. M., \& COBURN, C. A. Biological bank protection: trees are more effective than grasses at resisting erosion from major river floods. Ecohydrology, v. 8, n. 5, p. 772-779, 2015. https://doi.org/10.14233/ajchem.2016.19222

SANTOS, E. A., CORREIA, N. M., SILVA, J. R. M., VELINI, E. D., PASSOS, A. B. R. J., \& DURIGAN, J. C. Herbicide detection in groundwater in Córrego Rico-SP watershed. Planta Daninha, Viçosa, v. 33, n. 1, p. 147-155, 2015. https://doi.org/10.1590/S0100-83582015000100017

SANTOS, E. A.; SANTOS, J. B.; FERREIRA, L. R.; COSTA, M. D. \& SILVA, A. A. Fitoestimulação por Stizolobium aterrimum como processo de remediação de solo contaminado com trifloxysulfuron sodium.

Planta Daninha, Viçosa, v. 25, p. 259-265, 2007. https://doi.org/10.1590/S0100-83582007000200004

SCALON, S. P. Q.; MUSSURY, R. M.; RIGONI, M. R.; VERALDO, F. Crescimento de mudas de espécies florestais nativas sob diferentes níveis de sombreamento. Revista Árvore, Viçosa, v. 29, n. 1, p. 1-5, 2002.

SCALON, S. P. Q.; SCALON FILHO, H.; RIGONI, M. R.; VERALDO, F. Germinação e crescimento de mudas de Pitangueira (Eugenia uniflora L.) sob condições de sombreamento. Revista. Brasileira.

Fruticultura. Jaboticabal, v. 23, n. 3, p. 652-655, 2001.

SCOTT, S. L.; AARSSEN L.W. Within-species leaf size / number trade-offs in herbaceous angiosperms.

Botany, London. 2012. https://doi.org/10.1139/b11-106

SCHREIBER, F et al. Plants sensitive to clomazone in vapor phase. Ciência Rural, Santa Maria, v. 43, n. 10, p. 1817-1823, 2013. https://doi.org/10.1590/S0103-84782013001000014

SEVERINO, L. S.; CARDOSOS, G. D.; VALE, L. S.; SANTOS, J. W. Método para determinação da área foliar da mamoneira. Revista Brasileira de Oleaginosas e Fibrosas, Campina Grande, v. 8, n.1, p. 753-762, 2004.

SNIF- Sistema Nacional de Informações Florestais, Fonte: Brasil/MMA (2008) adaptado. INSTRUÇÃO NORMATIVA No 6, DE 23 DE SETEMBRO DE 2008 Acesso 27-07-2012. 
STEINGRAEBER, D. A. Phenotypic plasticity of branching pattern in sugar maple (Acer saccharum). American Journal of Botany, Lancaster, v. 69, p. 638-640, 1982. https://doi.org/10.2307/2443074

SULTAN, S. E. Phenotypic plasticity in plants: a case study in ecological development. Evolution \& Development, Malden, v. 5, n.1, p. 25-33, 2003. https://doi.org/10.1046/j.1525-142X.2003.03005.x

TANDY, S.; BOSSART, K.; MUELLER, R.; RITSCHEL, J.; HAUSER, L.; SCHULIN, R.; NOWACK, B. Extraction of heavy metals from soils using biodegradable chelating agents. Environmental Science Technology, Easton, v. 38, p. 937-944, 2004. https://doi.org/10.1021/es0348750

TOMCO, P. L.; HOLMES, W. E.; TJEERDEMA, R. S. Biodegradation of clomazone in a California rice field soil: carbon allocation and community effects. Journal of agricultural and food chemistry, Easton, v. 61, n. 11, p. 2618-2624, 2013. https://doi.org/10.1021/jf304692c

WHITMAN, T.; AARSSEN, L. W. The leaf size/number trade-off in herbaceous angiosperms. Journal of Plant Ecology, Reino Unido, v. 3, p. 49-58, 2010. https://doi.org/10.1093/jpe/rtp018 